Одсек за српски језик и лингвистику

Радослава Д. Глишовић, Западни универзитет у Букурешту

\title{
ИЗ КОЛАРСКЕ ЛЕКСИКЕ СЕЛА ЧЕНЕЈА (РУМУНИЈА)
}

\begin{abstract}
У раду се анализира лексика коларског заната из Ченеја. Добијена грађа упоређује се са оном забележеном и анализираном у монографији Војвођанска коларска терминологија из 1984. године. Грађа је забележна од последњег живог колара из Ченеја и врло је скромног обима јер је казивач многе лексеме, па и реалеме, заборавио. Материјал обилује лексемама германске провенијенције што је и било очекивано јер су коларски занат (и не само каларски) у Ченеј донели Немци. Обрађена су следећа семантичка поља: Називи за кола и њихове делове (предњи и задњи трап, точак, лотре, шараге, левча, руда) и Називи за особе које управљају колима. Грађа је лексички и творбено-семантички анализарана (суфиксална анализа и семантичка мотивација лексема). Готово целокупна сакупљена коларска терминологија Ченеја подудара се са оном из поменуте монографије, с напоменом да су у питању оба банатска говорна типа Ш-В дијалект као и смедеревско-вршачки дијалекат.
\end{abstract}

Кључне речи: Ченеј, српски говор, коларска терминологија, творбеносемантичка анализа, германизми.

\section{1. Увод}

село Ченеј први пут се помиње у документима 1221. године као посед Иштвана Итебеја, а затим више пута у 14. и 15. веку. Насеље се налази у западном делу темишварске жупаније, а сеоски атар граничи се са атарима села Кече, Карпиниша (или Грчаноша како га српски мештани зову), Побде, Ујвара, Пустињиша, Српског Итебеја, Хетина и Радојева. Поред села протиче река Стари Бегеј. До 1903. године село је било подељено на Српски и Хрватски Ченеј, а након те године до после Првог светског рата било је средиште среза са 14 окружних села. Године 1924. након коначног разграничења, Ченеј је уступљен Краљевини Румунији. Данас је и седиште

\footnotetext{
${ }^{1}$ gordanadragin19@gmail.com

${ }^{2}$ Рад је настао у оквиру пројекта „Истраживање културе и историје Срба у Румунији“ Центра за научна истраживања и културу Срба у Румунији, који финансира Савез Срба у Румунији
} 
истоимене општине у округу Тимиш у Републици Румунији. Удаљено је 28 километара од Темишвара ка румунско-србијанској граници. Сеоски атар је у равничарском делу Баната поред Бегеја. Банатским говорима шумадијско-војвођанског дијалекта, углавном, комуницира се у делимично српским селима у Републици Румунији уз границу са србијанским Банатом³. Северни део равног Баната, где се налази Ченеј, представља најбогатији крај у Румунији у којем живе Срби. По попису из 2002. године у Ченеју је живело 2013 становника, а од тога је 530 српске националности, тј. 26,3\% од укупног броја становника. Село је некада било насељено претежно Србима, а данас српско становништво чини тек нешто више од четвртине целокупне популације, односно скоро двоструко мање него што је Румуна (54, 4\%). Мађари и Немци чине заједно преко $17 \%$ од укупног броја становника. Почетком 19. века у Ченеј долазе Хрвати и Немци што је знатно допринело развоју места, а посебно занатске делатности. До Другог светског рата ово мултиетничко село са већинским српским становништвом имало је доста занатлија. У то време, занатлије, углавном Шваби (како их зову Ченејци), имале су своје радионице, а код њих су занат изучавале калфе и шегрти, већином Срби. До друге половине прошлог века када су кола била главно (и радно и парадно и путничко) превозно средство, коларски занат, поред ковачког, био је један од најцењенијих у селу. На селу су колари (и ковачи) и њихове породице уживали велики углед, а занат се обично преносио са оца на сина.

\section{2. О грађи}

Међутим, промењени услови живота на селу као и убрзана и неминовна модернизација утичу на измену реалија, па тиме и на нестанак лексема које их именују. Данас се за рад у пољу и превоз користе трактори и друга савременија превозна средства, а запрежна кола могу се видети само у неким сеоским двориштима или испред угоститељских објеката - као сувенир. Са нестанком кола, нестају и колари, а иста судбина чека и многе уско стручне термине везане за коларски занат. При сакупљању грађе користиле смо Упитник за коларски лексику који је састављен за потребе рада на књизи Коларска лексика Војводине аутора Г. Вуковић, Ж. Бошњаковића и Љ. Недељков са Филозофког факултета у Новом Саду.

Информатор, Милета Команов (1928-2018), у време нашег сусрета био је последњи колар у селу. По његовом сведочењу у другој половини прошлог века у Ченеју је било још четири колара, а и отац му се бавио коларским занатом и био шегрт код „неког Швабе колара”. Морамо поменути чињеницу да је наш информатор и поред добре воље да нам изађе у сусрет

\footnotetext{
${ }^{3} \mathrm{O}$ српским говорима граничних села и Ченеја писано је у више наврата (в. литературу).
} 
и одговори на свако питање из Упитника, ипак, многе називе заборавио, чак не може да се сети ни неких реалија па често одговара са „немам појма” или „ја не знам шта је то, нй ме иниеересйрало” или „питај ковача”.

Више детаља у вези са деловима кола, рецимо, информатор именује истом лексемом, као што је случај са лексемом ја̄pмац која у његовој меморији одређује следеће реалије 1. 'дуже дрво преко кракова и руде', 2. 'део између лотри на предњем и стражњем дела кола', 3. 'део који држи лотре да не спадну' и 4. 'предњи део кола за који се везују коњи'. Затим, за одредницу йò̄ūe $a$ наводе се три различита значења као 1. 'дрво које се налази испод срчанице и спаја предње кракове', 2. 'гвоздени део на средини краћег дрвета које носи патос и углављено је у лотре' и 3. 'део кола који служи за пењање’. Неколико пута, такође, не могавши да се сети српског назива, помињао је румунски. Данас је мало живих мештана који су у прошлости имали кола и превозили се њима да би нам могли одговорити прецизније на питања чији нам одговори недостају или су непотпуни.

С друге стране, монографија са којом поредимо нашу грађу, Војвођанска коларска терминологија (ВКТ), аутора Г. Вуковић, Љ. Недељков и Ж. Бошњаковића изашла је из штампе пре више од 35 година (1984) када је било сврсисходније сакупљати грађу од људи који су још увек имали кола и запрегу, него што је то данас.

Овако некомплетна грађа, ипак, доноси стару, скоро заборављену лексику која може бити од користи, не само лексиколозима и дијалектолозима већ и историчарима језика, етимолозима, етнолозима. Овом приликом бавићемо се лексиком тематских целина Називи за кола и ғихове делове (предњи и задњи трап, точак, лотре, шараге, левча, руда) и Називи за особе које управљају колима.

У монографији Војвођанска коларска терминологија (ВКТ) сакупљена је и обрађена грађа из 114 војвођанских села, а 36 их је из Баната. Сакупљена грађа из Ченеја биће изложена азбучним редом са значењем које је добијено од казивача, а затим упоређена са ВКТ (тј. у конкретним селима где је лексема забележена) са обавезно истакнутим значењем и евентуалним синонимима.

\section{3. Лексичко-семантичка анализа грађе}

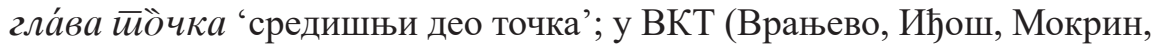
Тараш, Елемир, Меленци, Башаид Српска Црња, Радојево) син. су и: главчина, пањ, вратник

днӧ 'под кола'; у ВКТ син. су и: даске, лес, лиса, патос, под, подина, табан, таван

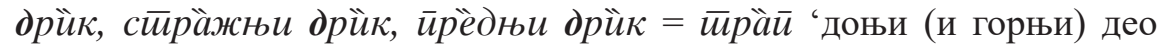

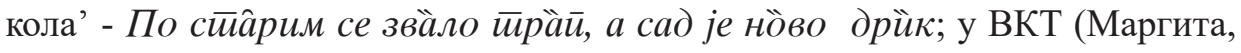
Делиблато, Уљма, Вршац, Велико Средиште, Бела Црква) и син. дрек 
дреиччаัник, дрейчаัник 'краће дрво (Х2) за које се везују коњи кад се прежу у кола'; у ВКТ (Алибунар) син. су и: ждрепчаник, дрвчаник, дручаник...

дрйчаัник в. дрейчӑник; у ВКТ (Мокрин, С. Црња, Радојево, Житиште, Перлез, Баваниште) син. су и: ждрепчаник, дрвчаник, дручаник...

ёш 'округли гвоздени прстен који повезује лотре и шараге' ...cмаั̆ьује и увећа̂ва кӧла; у ВКТ нема ове лексеме.

ја̄рмаи, 1. 'дуже дрво преко кракова и руде', 2. 'део између лотри на предњем и стражњем дела кола', 3. 'део који држи лотре да не спадну', 4. 'предњи део за који се везују коњи'; у ВКТ (највећи део Баната) син. су и:вагирача, јармак, јермани,

каре́лц̧а, коре́лц̧а 'мала затворена кола с једним точком које гура човек'; У ВКТ нема ове лексема, тамо је само колииа, док у Ч нема лексема трагаче, драгаче у истом значењу. Ова лексема, са фонетизмом корелияа, забележена је и у Сенпетеру у Румунији, Дески у Мађарској и Ђали у сверном Банату, на самој граници са Мађарском (РСГВ 4: 144).

кӓруца, ж. пл.т. 'фијакер,свечана покривена запрега на четири точка' - Ка̀руца нёкад бйла, а сӓ̀ је фија̄керска ко̆ла; у ВКТ (Падеј, Маргита) син. и ка̀руц̧е ж. пл.т.

ка̂pфе мн. 'усправни ступчићи на лотрама'; у ВКТ (Радојево, Долово, Маргита) син.су и: карве, карвице, карсле, карбе,

ко̆ла пл.т. 'општи назив за превозно средство на четири точка за преношење кукуруза, сена и сл. које вуку коњи или волови'; У ВКТ сви испитивани пунктови имају ову лексему са истоветним значењем.

коваิчки клйн 'ексер којим се прикрива шина на точак' у ВКТ само клин

ко́чија 'кола за превоз балвана, трупаца и сл.'; и ВКТ нема ове лексеме, док је у РСГВ под одредницом ко̀чја, поред упута на синонимну лексему каруце, дат следећи податак: „Једино је у једном месту у јужном Банату остала нејасна мотивација лексеме кочинска кола, према кочија за означавање радних кола" (159).

кочйјаш 'општи назив за човека који управља колима'; у ВКТ сп ${ }^{4}$

кочијаิши 'управља коњима седећи на колима'; у ВКТ сп

краัкови мн. 'део којим је руда спојена за трап'; у ВКТ син. су и: ласве, ластавище, ластине, пернице, праћка, рашье, свраке, сврачило, сврачине, шврачине, шкаре

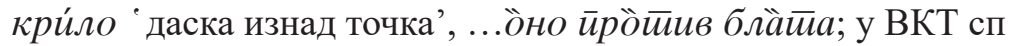

ку̀ка 1. 'гвоздени део који држи шараге'; у ВКТ син. су и: кљун, канце, мачке, пармак 2. 'округли гвоздени део на стражњем делу струке'; у ВКТ син. су и: копче, кљун, канце, мачке, пармак

\footnotetext{
${ }^{4}$ Ознака сп значи да је лексема забележена у свим испитиваним пунктовима.
} 
леิвча 'криво дрво које спаја точак и лотре '; у ВКТ сп

ло́йре пл. т. 'бочне стране на колима'; у ВКТ сп

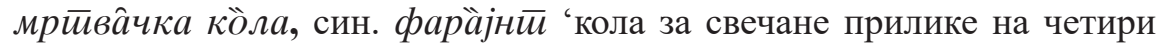

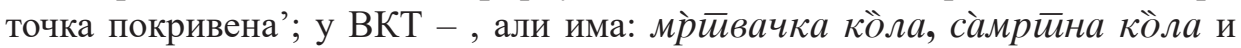
й̀̀̄ребна кӧла

нӓ̄илодак / на̄̄̄лойак 'део између металног обруча и чашице на осовине (6 комада)'; у ВКТ син. су и: гобеља, наплат, наплатак, наплетак, имирфенинг

на ка̂рфе ло́т̄ре в. лотре; у ВКТ лотре са карвама

зӓйворене ло́йре = ВКТ 'лотре од дасака'

ӧблог̄a 'део који се ставља на место шарага кад се превози ситан материјал '; у ВКТ са значењем 'гвожђе које штити доњу струку лотре од предњег точка' и син. кламфа, кланфа.

ӧбрйаj 'део кола кружног облика по којем се кола обрћу, покрећу'; у ВКТ син. су и: обртаљ, обртан, возаљка, клизаљка, клизача, обртач, обртел, пеглајз, пети точак, пошетаљ, пошетка, шестар, шеталица

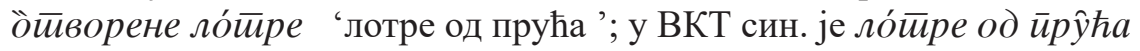

йӓјван 'коноп којим се учврћује терет на колима'; ВКТ $+{ }^{5}$

üйкса 1. 'гвоздена чашица на крају осовине'; У ВКТ са тим значењем су: пиксла, пиксна, капа, каписла,капсла, капсло, пушка, топ, тоцуа, чашица, чурка, итез, итезла, итезли, итесли, итеила, штеило, штезло, 2. 'гвожђе на којем се кола обрћу', 3. 'гвоздени део на којем су смештени точкови’

йомоัйн'ице, йомоัчнице, йомоัћницее 'водоравни дрвени део на лотрама', 2. 'уздужни додаци (увек у множини) на колима кад се вози сено’; у ВКТ и йомо̀ћние и помотнице

$\bar{u} о \bar{u} \bar{e} \bar{a}$ 1. 'дрво које се налази испод срчанице и спаја предње кракове'; у ВКТ $-{ }^{6}, 2$. 'гвоздени део на средини краћег дрвета које носи патос а углављено је у лотре'; у ВКТ -и 3. 'део кола који служи за пењање напред ; у ВKT +

ирёчег̄e зӓдње 'крајње пречке на лотрама са задње стране'; у ВКТ йреччегеe йрёдње 'крајње пречке на лотрама са предње стране'; у ВКТ päqp 'метални оков на точку кола'; У ВКТ (потврђено само у Радојеву на самој граници са Румунијом, најближем селу са србијанске стране) син. су и: иина, обруч, подлуч

pýda 'дугачко дрво на колима из које се упрежу коњи'; у ВКТ сп

сёдишйе 'два дрвета која висе на кукама преко којих је даска за седење'; у ВКТ сп 'седиште на колима без федера'; син. су и: седалица, седало

cùus 'део кола на коме седи кочијаш '; у ВКТ сп, в. седиште 'седиште на колима са федерима'

\footnotetext{
${ }_{5}^{5}$ Знаком + обележено је присуство идентичне лексеме са идентичним значењем.

${ }^{6}$ Знаком - обележено је одсуство дате лексеме.
} 
cüus - федер 'седиште на колима са федерима'; у ВКТ -

cüйца 'дрвена шипка између наплотка и средине точка'; у ВКТ син. су и:збица, жбица, палщи, паоци, ипище

сречӓница / срчйаница 'дуже дрво које спаја трапове'; у ВКТ син. су и: серчаница, сречаница, стрчаница, итрчаница

cйру̀ка (ло́йре) горња с, долња с, средња с. 1. 'водоравна пречка на лотрама'; Ч у ВКТ + и 2. 'краћа усправна дрва на шарагама'

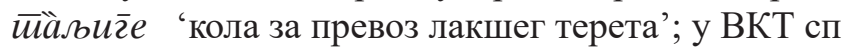

चйучак 'округли део на којем је колска конструкција који омогућује да се кола лако крећу'; у ВКТ сп

च̈ӓрнице 'лака кола на која се ставља даска изнад точкова са 4 точка'; у ВКТ и син. таљиге

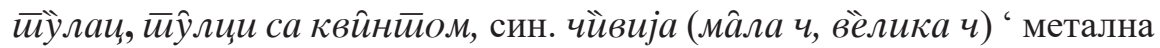
кратка цев у главчини кола'; у ВКТ син. су и: тулак, туљьак,чивија

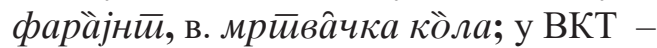

фија̄кер, син. фија̄керска ко̆ла, в. каруиза; у ВКТ сп

фија̄керска кӧла в. каруца у ВКТ - (само фијакер)

черг̄âuка ко̆ла 'циганска шарена покривена кола имају шатру'; у Алибунару на самој граници са Румунијом (ВКТ и син. са циганска кола)

чйвија, ма̂ла чйвија, вѐлика чйвија в. тулац; у ВКТ сп

miа̀раг̄ље пл.т. ‘ ограда на предњој и задњој страни кола’; у ВКТсин. mapaze

uаре́ūe пл.т. ‘ кола за преношење лакшег терета у која се упреже један коњ’ у ВКТ-

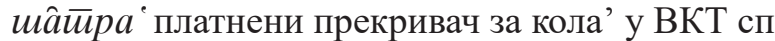

шйниеерска кӧла ‘ кола у која се скупљају пси луталице'; у ВКТ сп

шйнйер човек који сакупља и превози псе луталице, вози шинтерска кола'; у ВКТ сп

шй̀ $к е$ мн. 'усправне (металне) шипке на шарагама'; у ВКТ син. су и: палице, запињачи, кушище, палщчи, струке, чивије, шипке

\section{4. Творбено-семантичка анализа грађе}

скренућемо пажњу, овом приликом, само на неке најмаркантније детаље творбено-семантичке анализе наше грађе.

Као општи назив готово увек јавља се проста лексема, без фонетско-

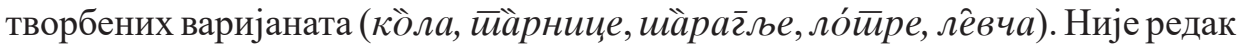
случај да се једна лексема јави са различитим фонетизмом (сречаัница, срчӓнице йомоัйн' ице, йомоัчнице, йомоัћнице, нӓйлодак / нӓйлойак). Мада у грађи преовлађују просте лексеме, забележене су и сложене. Ради се углавном о независним синтагмама (шйнйерска ко̀ла, черг̃âшка ко̀ла, 


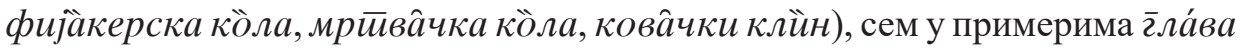

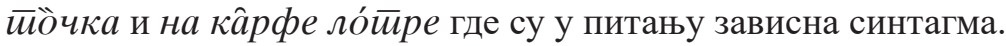

Што се тиче суфиксалне анализе, види се да се као фреквентни истичу следећи суфикси: -а(е)га (потега, пречега) -ај (обртај), -ак (наплодак, наплотак), -аи (јармаи, тулаи), -ица/(н)ице (корелиа, срчаница, помоћнице, тарнице), -л'е (шарагље), -ник (дрпчаник, дрепчаник) и сл.

Семантичка мотивација која је послужила као основ за образовање лексема може бити различита. Лексеме у функцији општих назива готово увек су непровидне мотивације (кола, точак, левча, шарагље). Издвајају се сложене лексема које су мотивисане посредством места које заузимају у односу на неке друге делове (иирёчегег зӑдње, иррёчегее иирёдње, сиирӑжњи дрйк, ирёељњ дрйк, гоюрња сиирйка, долљња сииру̀ка, срёдња сиирйка). Знатно је мање оних са мотивационом базом која се тиче величине или трајног стања именованог предмета (вѐлика чйвија, ма̂ла чйвија; зӑйворене лóūpe, ò̄üворене лóūpe). Намена или припадност као мотивациона база бележи се у примерима: шйниеерска ко̀ла, черг̃̂िка ко̀ла, фија̀керска

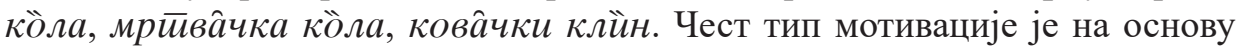
анатомске лексике (глава, кракови, крило, кука, срчаница, сречанииа). На основу сличности са неким предметима за општу употребу функционишу лексеме дно, шатра, шипка.

С обзиром на чињеницу да је грађа сакупљена само из једног пункта

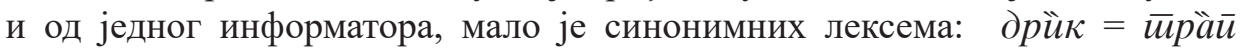
(По сииарим се звӑло тираัт, а сад је но̆во дрйк), фија̀кер в. Каруца,

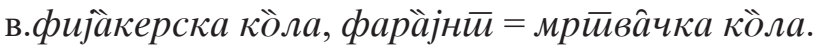

Велики је број страних лексема у посматраним семантичким пољима (називи за кола и њихове делове и називи особа које управљају колима). Међу њима је, очекивано, највише германизама (дрик, лотре, раф, сии, спица, фарајнт, иарагље, шинтер) и тек понеки турцизам (пајван, чивија) и романизам француског (фијакер) или италијанског порекла (каруц̧а).

\section{5. Резултати поређења грађе из ченеја и из војводине}

Готово целокупна сакупљена коларска терминологија Ченеја подудара се са оном из монографије Војвођанска коларака терминологија. Како је речено на почетку, њихово значење у Ченеју врло често је различито (потпуно или у детаљу) од онога у монографији. Ипак, мали је део лексема који је нотиран само у Ченеју, а не и широм Војводине. То су следеће лексеме: ёш 'округли гвоздени прстен који повезује лотре и шараге (смаัњ ује и увећа̂ва кӧла)'; каре́лца, коре́лц̧а 'мала затворена кола с једним точком које гура 
човек '; ко́чија ${ }^{7}$ 'кола за превоз балвана, трупаца и сл.'; йрѐчеӣe зӑдње 'крајње пречке на лотрама са задње стране'; йреучеге е йё̀ње 'крајње пречке на лотрама са предње стране'; фија̄керска ко̆ла в. мрйва̂чка ко̆ла, каруц̧а; фрарӓјнй 'кола за свечане прилике на четири точка покривена' и шаре́йe 'кола за преношење лакшег терета у која се упреже један коњ'.

Поред тога, неке од нотираних лексема у нашој грађи потврђене су у монографији само у Банату са србијанске стране. То су следеће лексеме:

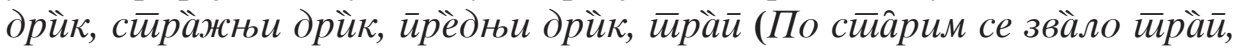
а сад је но̆во дрйк); дрейчӑник са значењем 'краће дрво (Х2) за које се везују коњи кад се прежу у кола' (забележена је само у Алибунару у непосредној близини границе са Румунијом) и рӓф ‘ метални оков на точку кола' забележено само у Радојеву на самој граници са Румунијом.

\section{1. ЗАКЉУЧАК}

Поменута монографија обогаћена је лексичким картама на којима се прати ареални распоред посматраних термина. Поредећи нашу грађу са оном из монографије и са мапираном грађом која се односи на Банат, долази се до закључка да се подударања крећу час са кикиндском, час са тамишком говорном зоном шумадијско-војвођанског дијалекта што у потпуности одговара прелазном статусу ченејског говора између ова два говорна типа (П. Ивић и др, 1997; Драгин, 2013; Радовановић, 2017). Важно је истаћи и податак да има лексема које су идентичне са онима у говору села смедеревско-вршачког дијалекта у Србији (дрйк, сиирӑжњи дрйк, дйрёдњи дрйк. - Маргита, Делиблато, Уљма, Вршац, Велико Средиште, Бела Црква; дрейчӓник - Алибунар; ка̂pфpe - Радојево, Долово, Маргита и сл) што само још више наглашава прелазност српског говора Ченеја.

\section{Литература}

Бошњаковић, Радан, 2010: Ж. Бошњаковић, М. Радан, Досадашња истраживања о утицају румунског језика на лексику српских говора румунског дела Баната, Јужнословенски фололог 66, Београд, 135-161.

Вуковић и др, 1984: Г. Вуковић, Ж, Бошњаковић, љ. Недељков, Војвођанска коларска терминологија. Нови Сад : Филозофски факултет, Институт за јужнословенске језике

Драгин, 2006: Г. Драгин, Балканизми у Банатским говорима шумадијсковојвођанског дијалекта на територији СЦГ и Румуније, у: Probleme de filologie slava, Timisoara, 44-58.

\footnotetext{
${ }^{7}$ Код ове лексеме упитно је и значење јер је супротно од значења у РМС лака кола с йокрейним кровом).
} 
Драгин, 2013: Г. Драгин, Прозодијске особине шумадијско-војвођанских говора у румунском Банату, у: Српско језичко наслеђе на мултикултурном простору Баната, Темишвар, 61-74.

Драгин, 2013: Г. Драгин, Неке фонетске особине говора Ченеја (у Румунији), Језиии и културе у времену и простору II/2, Нови Сад, 379-384.

П. Ивић и др, 1997: П. Ивић, Ж. Бошњаковић, Г. Драгин, Банатски говори шумадијско-војвођанског дијалекта (друга књига: морфологија, синтакса, закључци, текстови), СДЗб, къ. XLIII, Београд, 1-586.

Марић, 2002: Б. Марић, Из лексике Ченеја (Румунски Банат), у: ППЈ, књ. 33, Нови Сад, 258-326.

Попов, 2014: И. Попов, Споменичко наслеђе Ченеја, Темишвар, 7-74.

Радовановић, 2017: Д. Радовановић, Теренски записи из Ченеја, у: Исходишта 3 , Темишвар, 345-356.

РСГВ 2000-2010: Д. Петровић (ред), Речник српских говора Војводине (1-10), Матица српска, Нови Сад.

Гордана С. Драгин

Радослава Д. Глишович

\title{
ИЗ ЛЕКСИКИ ТЕЛЕЖНОГО РЕМЕСЛА СЕЛА ЧЕНЕЙ (РУМЫНИЯ)
}

\begin{abstract}
Резюме
В работе проанализирована лексика тележного ремесла в селе Ченей. Полученный в данном исследовании материал сравнивается с тем, который собран и анализирован в монографии Војвођанска коларска терминологија (Терминология тележного ремесла Воеводины) появившейся в 1984-ом году. Сведения получили от последнего живого тележного мастера Ченея и отличаются они достаточно скромным объемом так, как наш информант забыл много лексем, в том числе и реалем, которые называют их. В материале очень много лексем германского происхождения, как и надо было ожидать потому, что тележное ремесло (причем не только тележное) в Ченей и принесли немцы. Обработаны следующие семантические поля: Названия телеги и ее частей (передняя и задняя оси, колесо, дышло, „лотре“, „шарагље“, „левча“) и Названия особ, которые управляют телегой. Материал анализирован лексически и структурно-семантически (суфиксальный анализ и семантическая мотивация лексем). Почтився собранная тележная терминология Ченея совпадает с той из упомянутой монографии, с уточнением что речь идет об обоих банатских типах говоров Ш-В диалекта, а тоже о смедеревско-вршацском диалекте.
\end{abstract}

Ключевые слова: Ченей, сербский говор, коларская терминология, структурносемантический анализ, германизмы. 